\title{
The Ontological Metaphor In Mambere Tungkot, Duda-Duda, And Sulang- Sulang Pahompu In Batak Simalungunese Tradition In North Sumatra, Indonesia
}

\author{
Martina Girsang ${ }^{1}$, Charles David Marudut Silalahi ${ }^{2}$, Elita Modesta Br Sembiring ${ }^{3}$, Srisofian \\ Sianturi $^{4}$ \\ ${ }^{123}$ Universitas Methodist Indonesia \\ ${ }^{4}$ Universitas HKBP Nommensen Medan \\ Email: martinagirsang253@gmail.com
}

\begin{abstract}
This paper describes and analyzes the ontological metaphor language in a traditional Batak Simalungunese tribe, Mambere Tungkot, Duda-Duda, and Sulang-Sulang Pahompu in North Sumatra, Indonesia. This study aims to present an analytical view of the customary tradition of thanking parents for their contribution to one's life. This is carried out in regular conversation through the language of metaphors, in particular, ontology metaphors. Ontological metaphors describe human qualities that are given to nonhuman entities (Kovesces, 2010: 33-38). This study applies the descriptive qualitative method to discuss the ontological metaphor depicted in the traditional ceremony. The data of the research were taken from the utterances of the speakers, namely: master of the ceremony, parents, and children involved in the ceremony. The concept of this study is the communication theory in the context of the ontological metaphor to analyze the data. The result of the study shows that most of the utterances in the traditional ceremony use ontological metaphors.
\end{abstract}

Keywords: Ontological metaphor, Communication theory, Mambere Tungkot, Duda- Duda, SulangSulang Pahompu.

\section{INTRODUCTION}

\section{Background of the Study}

Metaphors can be found in every language. A metaphor is one of the most interesting modes of human interaction through language it is the reflection of each language user's cultural background while being a universal phenomenon within all languages. Kovecses (2003:4) in the cognitive linguistic perspective along with Lakoff (1987), defines a metaphor as the reflection of a mental process by which people understand one conceptual domain in terms of another conceptual one; Gibbs (1994: 78) defines a metaphor as a comparison between two terms that is made in order to explore the nature of one. This is in line with the definition of Grice (1975:4) which says that a metaphor is like indirect speech in expressing a distinctive meaning intended by the speaker; According to Shen (2000: 45), a metaphor is widely viewed as the (selective) mapping of properties from one conceptual domain (the source) onto another (the target). Based on these definitions, it can be said that a metaphor is a word or a phrase used to describe something or someone in a way that is different from its normal use. This is done in order to portray that those two things have the same qualities and to make the description more powerful. From this perspective, it can be noted that a metaphor has, at least, three characters: 1) a metaphorical interpretation is different from its normal one; 2) a metaphor consists of two or more things compared; and 3) a metaphor makes the implied meaning more powerful.

Metaphorical language is divided into (1) the conventionality of metaphor, (2) the cognitive function of metaphors, and (3) imageschema of metaphor. The cognitive function of metaphors in further divided into a) structural metaphor; b) ontological metaphor; c) orientational metaphor.

Ontological metaphors provide much less cognitive structuring for target concepts than structural ones do. Their cognitive job seems to be to "merely" give a new ontological status to general categories of abstract target concepts and to bring about new abstract entities. What this means is that people conceive of their experience 
in terms of objects, substance, and containers. Since their knowledge about objects, substances, and containers is rather limited, people cannot use these highly general categories to understand target domains. This is where structural metaphors enter. They provide an elaborate structure for abstract concepts, as discussed.

Furthermore, an ontological metaphor is a metaphor for conceptualizing thoughts and, experiences, and then processes it into something which is more concrete and based on physical properties. George Lakoff and Mark Johnson stated that their experiences with physical objects (especially our own bodies) provide the basis for an extraordinarily wide variety of ontological metaphors, that is, ways of viewing events, activities, emotions, ideas, etc., as entities and substances (2003:15). Understanding our experiences in terms of objects and substances allows us to pick out parts of our experience and treat them as discrete entities or substances of a uniform kind. Once we can identify our experiences as entities or substances, we can refer to them, categorize them, group them, and quantify them and, by this means, reason about them.

This study will focus to -analyze the utterances of the speakers in the Batak Simalungunese traditional ceremonies of Mambere Tungkot, Duda-Duda, and SulangSulangPahompu in North Sumatra, Indonesia. This will be done by using the communication theory and ontological metaphor, one of the cognitive functions of metaphors since most of the data content of physical object, substance, and container that related to Non-physical or abstract entities, (Kovesces: 2010: 33-38).

In Mambere Tungkot, Duda-Duda, and Sulang-Sulang Pahompu the choice of language is to convey specific messages with the intention of describing each step of the ceremony. By having the right utterance, there will be no misunderstanding between the listener and the speaker. The clarity of communication is most significant here. There is however the use of some metaphorical language, in this case, the use of ontological metaphors. Even though metaphors are used, the speaker should convey the messages clearly so that the listeners comprehend the messages clearly as well. Only then can the communication be called successful.

However, this communication does not always run smoothly because of some reasons. Firstly, the parents who are being addressed in the ceremony may not be able to hear or comprehend due to reasons of age. These aspects prompt the speaker to opt the right utterance so that the elderly parents can understand what the speaker really means. Secondly, in the ceremony, the speaker has his own speaking style with different instructional methods and approach in carrying out the ceremonious rituals. According to Richard (2002) said speakers differ in the way they see their role in the program they lead. The type of ceremony they perform or their speaking strategies; all lead to differences in the speaker's speaking style.

\section{The previous study}

Among the researches on metaphors, there is no single research about the metaphorical language in Mambere Tungkot, Duda-Duda, and Sulang- Sulang Pahompu. However, the followings are relevant:

1. Ha Hoang, 2014. Metaphor and Second Language Learning: The State of the Field. It analyzes about the metaphor that is considered a critical component of every day and specialized language, thought, and communication that has been examined in the context of learning a second language.

2. Uswati, Jufri, Rusdi Noor Rosa, 2012. Types and Functions of Metaphor in Pasambahan Script of Wedding Party in KamangAgam. It explores about how to find the types and the functions of the metaphor in a wedding party in KamangAgam that are used by the speaker.

\section{The Purpose of the Sulang-Sulang Ni Pahompu}

- Furthermore, according to Sumbayak (2001); Girsang and Sembiring (2018) the purposes for holding the traditional ceremony in Batak Simalungun tribe include: a) the children and grandchildren ask for apologies from their parents; b) they ask for their parents' blessings; c) the ceremony is a reminder to the children and the grandchildren that they must thank God for giving them their parents; d) the ceremony is a reminder to the children and the grandchildren that they too will grow old someday. 


\section{RESEARCH METHODOLOGY}

\section{Research Design}

This research uses the qualitative research method and the data is ordinarily expressed in qualitative terms. This is because the data analysis is not employed in hypothetical test. The objective explanative is the suitably fixed design of this research. The decision of determining this research design is highly dependent on the nature of the research, that is, to objectively describe and analyze the use of ontological metaphor language in "Mambere Tungkot, Duda-Duda, and Sulang-Sulang Pahompu" in the traditional ceremony of the Batak Simalungunese tribe in North Sumatra, Indonesia.

\section{The Subject of the Study}

The subject of the study is the Anak Boru $J a b u$ (the master ceremony and the speakers who are chosen by the children) categorized as the data in this research. Data are defined as the raw materials collected by the researchers from the world they are studying; They are the particular set that form the basis of the analysis (Bogdan and Biklen, 1992:106). The data was collected from the utterances, the contexts, and the conversations between the Anak Boru Jabu 'master ceremony', niombah 'the children', orang tua 'the parents' and other kin. Specifically, the utterances of all the children and grandchildren data. Once collected, the data is recorded and transcribed in order to further analyze the utterances.

\section{The Technique of Data Collection}

In conducting this scientific research the systematic steps of data collection are followed. The chronological sequences of obtaining the data for this research is as follows:

1. Observing the Simalungun Batak traditional ceremony Mambere Tungkot, Duda-Duda, and Sulang-Sulang Pahompu".

2. Recording all the conversation between the master ceremony and the speakers (children, parents and other kin) related to the ontological metaphor.

\section{The Techniques of Data Analysis}

The techniques of data analysis used in this research are:

1. Transcribing all the available utterances,

2. Identifying the transcribed text by underlining and categorizing the portion of ontological metaphor language in the traditional ceremony,

3. Interpreting the data with references to the basis of the portion of ontological

- metaphor,

4. Describing the conclusion of the analysis.

\section{RESULTS AND DISCUSSIONS Results}

The data in this paper displays the ontological metaphors that were taken from the communication or utterances among parsahap 'master ceremony', Niombah ' children', Orang Tua ' parents' in 'Mambere Tungkot, DudaDuda, and Sulang-Sulang Pahompu" in Batak Simalungunese tradition in North Sumatera, Indonesia. It is a traditional ceremony in Batak Simalungunese tribes, in North Sumatra, Indonesia which is organized by children and grandchildren as a form of showing their respect toward their parents who have loved and care for them and given them a good life. So the children hold the ceremony by giving a special food to their parents, such as dayok na binatur ( a cock is cut, cooked, and arranged on a plate), giving some new clothes to their parents, Tungkot (a walking stick), and a Duda-Duda ( a thing for mixing some leaves which is called as Napuran ), and many other things. In order to run the chronology of the ceremony well, one needs a good raja parsahap (a master ceremony) who leads and describes any ontological metaphor language by any symbols in the ceremony.
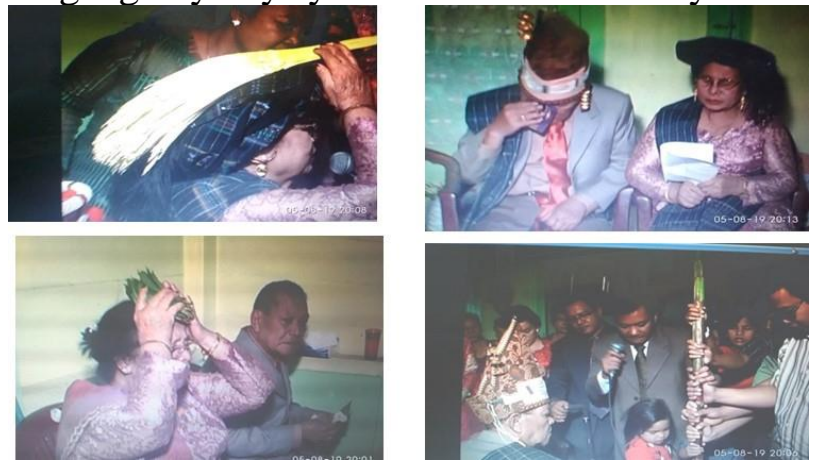

In this ceremony, the choice of language is made to convey specific messages with the intention of describing each step of the ceremony. By making the right utterance, there will be no misunderstanding between the listener and the speaker. Particularly in the Mambere Tungkot, Duda-Duda, and Sulang-Sulang 
Pahompu, although there is some ontological metaphor language usage, however, the speaker should convey the messages clearly so that the listeners comprehend the messages clearly. Only then can the communication be called successful.

The data of the study is segmented into parts of the source language to the target language in table form. Then the utterances of each speaker involved in the ceremony that contain of the ontological metaphor are recorded.

The analysis of the data is done using two techniques: Transcribing all the utterances based on the role in the traditional ceremony. Identifying the $e^{-}$transcribed text by underlying and categorizing the proportion of the ontological metaphor language in the traditional ceremony party.

\section{Transcribing all the utterances.}

Table 1. Data of Ontology Metaphor Found in Parsahap " Master Cermony's" Utterance

\begin{tabular}{|c|c|}
\hline Source Language & Target Language \\
\hline $\begin{array}{r}\text { Bere nasiam ma bani orangtua } \\
\text { on napurantiar, } \\
\text { pangir,pahean na jenges, sipanganon } \\
\text { namantin, } \\
\text { ase marpasu } \\
\text { pasu sidea bani } \\
\text { nasiam boi goluh nasiam } \\
\text { lambin tiar son } \\
\text { gon,partiar ni napuran } \\
\text { on,manektek ganup namilas } \\
\text { namohop, } \\
\text { Songon partektekni aek } \\
\text { pangir on. }\end{array}$ & $\begin{array}{l}\text { "Please give the betel } \\
\text { leaf, muddled lime, } \\
\text { good clothes, delicious } \\
\text { food to your parents, so } \\
\text { that you are all blessed } \\
\text { by your parents to have } \\
\text { a better life, run your } \\
\text { life smoothly, and have } \\
\text { good health." }\end{array}$ \\
\hline
\end{tabular}

Below is the analysis of utterances. The utterances were taken from the conversation of parsahap 'master ceremony', niombah 'children', and orang tua 'parents' in the traditional ceremony.

Ceremony':

Utterances of Parsahap 'Master

Bere nasiam mabani orangtua onnapuran tiar,pangir, pahean na jenges,sipanganon na mantin,ase marpasu-pasu sidea bani nasiam boi goluh nasiam lambin tiar songon,partiar ni napuran on, manektek ganup na milas namohop, songon partektek ni aek pangir on/ Please give the betel leaf to your parents/ muddled lime/ good cloths/delicious food/so that you are all blessed by your parents to have a better life/ run your life smoothly/ have good health.

As mentioned previously, the ontological metaphor is one type of metaphor in which many activities, emotion, and ideas or human qualities are given to non- human ones. In the Batak Simalungunese tribe, especially in the traditional ceremony, such as "Mambere Tungkot, Sulang Sulang ampa Duda-Duda Pahompu, the abstracts can be seen by the utterances of the master ceremony, namely:

a. Please give the betel leaf to your parents, so that you are all blessed by your parents to have a better life, run your life smoothly, have good health."

The betel leaf is symbolized as a medium for the children opening talks; the medium to glue hearts and minds; it is also beneficial for health. Furthermore, the betel leaf is also the medium for the children asking for the parental blessings.

b. The master ceremony also guides the children to shower the parents with 'unte pangir' muddled lime' by saying: Please give muddled lime to your parents, so that you are all blessed by your parents to have a better life, run your life smoothly, have good health, and it will clean all the dirt from one's body and soul; the misfortunes of life will go far away, the disease will also go away, conversely sustenance will increase, and at the same time the children will get blessings of abundant fortunes".

In this case it can be seen how the Simalungunese society view the entity of 'unte pangir' muddled lime' in reference to the abstract ones as if it can bring all the best fortunes to humans.

c. Furthermore, the master of ceremony ask for the children, normally the eldest son and his wife, representing the other kids to dress the parents with a new set of good clothes by saying: "Father and mother, we dress you both with the new and beautiful clothes. Please wear it so that your body is warm, and your heart is joyful. When we were still kids, you would always dress us. Presently, it is our turn to dress you both. We beg you to bless us all, so that our lives can always be fresh and beautiful like these cloths, and we have good health". 
The good clothes are personified as the human being who can warm their parents' body; they will protect their parents' body from illness, the ornate clothes will also increase their parents' dignity. When parents feel that they are treated respectfully and politely by their children, of course the parents will feel happy, and they will bless their children. By the blessing of their parents, the children's lives will be prosperous.

The discussions above show us the ontological metaphor of the napuran tiar 'betel leaf', unte pangir 'muddled lime', the new and beautiful clothes are related to the entities which abstract them to the lives of human beings, such as : a better life, blessings' joy, and good health, etc.

Table 2. Data of Ontology Metaphor found in Niombah 'Children's Utterance

\begin{tabular}{|l|l|}
\hline Source Language & Target Language \\
\hline $\begin{array}{l}\text { On ma inang, bapa napuran } \\
\text { tiar, ase tiar ganup goluh nami. }\end{array}$ & $\begin{array}{l}\text { "Father/mother here is the pure betel leaf, } \\
\text { hopefully our life will be pure as the betel } \\
\text { leaf." }\end{array}$ \\
$\begin{array}{l}\text { On ma inang, bapa,sipanganon namantin, } \\
\text { tungkot na matobu,janah pakean } \\
\text { namajenges. }\end{array}$ & $\begin{array}{l}\text { arranged in a plate as the symbol of good } \\
\text { manner in live. }\end{array}$ \\
& $\begin{array}{l}\text { Na malum is made of a cooked pig fat. The } \\
\text { sauce is taken as the symbol of healthy. }\end{array}$ \\
\hline
\end{tabular}

\section{2 . Utterance of Niombah (children)}

In this opportunity the Niombah" the children's' utterances are:

a. On ma inang, bapa napuran tiar, ase tiar ganup goluh nami 'Father/mother here is the pure betel leaf/ hopefully our life will be pure as the betel leaf. Just like the utterances of the master ceremony above, which abstracts the activity, the children also do the same with their beliefs about the betel leaf blessing inside that they gave to their parents. It symbolizes the pureness of their life. The belief is that, their fortunes will be better than earlier after they give the bettel leaf to their parents. When they give the betel leaf to their parents, it will be received while praying to God and asking for God's blessing for their children.

b. Furthermore, the master ceremony also asks the children to give some materials to their parents as part of the ceremony, such as Dayok na binatur a food which is made of a chicken cock that is arranged in a plate as the symbol of good manners in life, by saying: "father, and mother, here is a dayok binatur. This is only a medium for you to give us your blessing. Please father, and mother, bless us all, so that we have good manners like the manners of the dayok binatur, such as protection, hard work, cleanliness, regularity of life, discipline, and courage."

In Batak Simalungun tribe there is a tradition of giving a dayok binatur in a special event. The dayok binatur is personified as good where the dayok always wakes up early in the morning, working hard, protecting its couple and kids safely, and back to its cage in the evening. So the dayok runs its life regularly. In the Mambere Tungkot and Sulang Sulang Pahompu tradition, the children give special food to their parents because they have got their parent's affection, they got good education, they were cared for, and protection as been symbolized by the dayok binatur. So, in this case, it can be seen how the concrete one is projected into the abstract one by giving the dayokbinatur to their parents, with the hope that the children will get the dayokbinatur's manner in their life.

c. The master ceremony also guides the children to give Namalum to their parents. It is made of cooked pig grease, and the sauce is taken as a symbol of health. The children said: "Father, and mother, here is the namalum food. Please eat the meat, and drink the broth. After that give your blessing to us, so that our lives can be as enjoyable as this food, and our fortune can improve, our body and soul will be more joyful".

In this ontological metaphor case, the $\mathrm{Na}$ malum is represented as a food that gives good health to whoever eats and drinks it. Namalum is only cooked pig grease, but it is symbolized as human qualities that can cure sickness, it can even give spirit to people.

The master ceremony also guides the children to give Mumbang 'tender coconut' to their parents by saying:" Father, and mother, here is the Mumbang 'tender coconut' for you to drink. We ask for your blessing through the Mumbang 'tender coconut' so it can provide pleasure and smooth sustenance for us".

In Simalungunese tribe there is a belief that by drinking the mumbang will give abundant life. It is based on the coconut plant that can be 
useful from the root till the leaf. So in this case, the coconut is represented with human qualities and it is figured as an abstract ones, namely abundant with life.

d. The master ceremony also guide the children to give Nitakgabur 'soft bread' to their parents by saying:" Father, and mother, here is Nitakgabur 'soft bread'. Please eat it, and hopefully by eating it you bless us all so that our lives can be sweet, soft, and our sustenance is smooth".

In this case, the concrete of the Nitakgabur is symbolized as the thing that can give a wonderful life to the people who eat it. It is because the Nitakgabur is made from a mixture of rice, flour, palm sugar, pepper, coconut, and salt. All the ingredients are ground until soft, then formed it into small pieces. It tastes delicious. So the deliciousness of the Nitakgabur is personified as the thing that can give a wonderful live abstractly. That is one reason the children give it to their parents because they have got a wonderful life from their parents.

e. The master ceremony also guide the children to give Pisang namatobu 'banana' to their parents by saying:" "Father, and mother, here is Pisang namatobu 'banana'. Please eat it and bless us all with the sweet and delicious taste of the banana into our lives, so that we can make you happy in the end of your life".

As we know that a banana is sweet, soft, and nutritious. By consuming it the life of the people will be good and happy. So in this case the banana's taste is symbolized as giving a beautiful life to people. At the same meaning it is the field of the ontological metaphor which abstracts the concrete one.

$\mathrm{f}$. The master ceremony also guides the children to give Dengke birong 'black fish' to their parents by saying: "Father and mother, here is Dengke birong 'black fish', please eat it, and give your blessing to us as much as the expensive price of the fish" "So it can be seen by the context how the black fish through the parents' blessings can give the precious value of life to the children. This is the ontological metaphor process which abstracts the concrete of the black fish.

In the traditional party, such as Mambere
Tungkot and Sulang Sulang Pahompu, the children prepare the most expensive black fish. It is the way of the children to appreciate their parents who struggled with their lives for the sake of the children's good lives. That's why the children make them happy.

g. The master ceremony also guides the children to give Rudang 'the flower of areca nut' as the symbol of beautiful live to their parents by saying:" "Father, and mother, here is Rudang 'the flower of areca nut' as a symbol of a beautiful life. The mother accepts it and puts it on her head. Then the mother says: I bless you - all this Rudang 'the flower of areca nut' makes your life beautiful.

$\mathrm{h}$. The master ceremony also guides the children to give tobu 'cane' to their parents by saying: "Father and mother, here is a tobu 'cane'. Since our childhood till we got married, we have all been your stick. Hopefully our life will be as sweet as the sugar cane. Please use the cane stick in guiding us all in the way of life".

From the explanations above, it can be seen that the entities of pure betel leaf, Dayoknabinatur (food which is made of a chicken cock and arranged in a plate), the namalum food, Mumbang (tender coconut), Nitakgabur (soft bread), Pisangnamatobu (banana), Dengkebirong (black fish), give Rudang (the flower of areca nut), tobu (cane), are all abstracted to the good life, happiness, protection that related to the ontological metaphor process.

Table 3. Data of Ontology Metaphor Found in

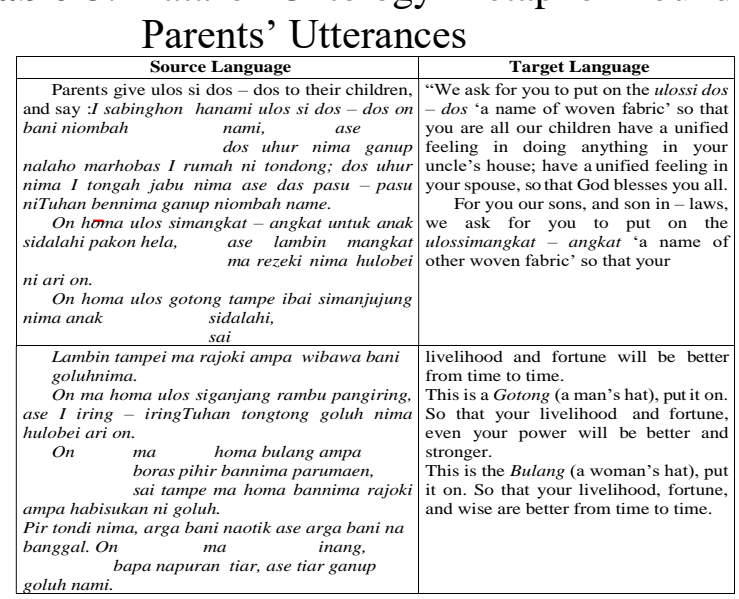




\section{Utterances of orang tua 'Parent':}

Parents give ulos si dos - dos 'the name of a handicraft' to their children, and say : "We ask for you to put on the ulos si dos-dos, so that you will have a unified feeling in doing anything in your uncle's house; have a unified feeling in your family, so that God blesses you all. In this utterance of parents, it can be seen how a concrete thing or entity such as the ulossi dos dos 'the name of a handicraft' unites the children's feeling.

Furthermore the parents also say their utterances to their sons, and sons in law: "we ask for you to put on the ulos si mangkat - angkat, so that your livelihood and fortune will be better from time to time.

Then the parents give a Gotong (a male's hat), to their son (s) by saying: put it on. So that your livelihood and fortune, even your power will be better and stronger.

They also continue giving a Bulang (a female's hat) to their daughters and say: put it on, so that your livelihood, fortune, and wise are better from time to time.

From the above explanation, it can be seen that ontological metaphors where the entities of a Gotong (male's hat) and Bulang (a female's hat), are abstracted to the human being that personify fortune and wisdom.

\section{Discussions}

For most people, a metaphor, in this case an ontological metaphor is a device of the poetic imagination and the rhetorical flourish - a matter of extraordinary language. Moreover, an ontological metaphor is viewed as a characteristic of language alone, a matter of words rather than thought or action. For this reason, most people think they can get along perfectly well without metaphors. This study finds the contrary, that ontological metaphors are pervasive in everyday life, not just in language but in thought and action. Our ordinary conceptual system, in terms of which we both think and act, is fundamentally metaphorical in nature.

The concepts that govern our thought are not just matters of the intellect. They also govern our everyday functioning, down to the most mundane details. Our concepts structure what we perceive, how we get around in the world, and how we relate to other people. Our conceptual system thus plays a central role in defining our everyday realities. If we are right in suggesting that our conceptual system is largely metaphorical, then the way we think, what we experience, and what we do every day is very much a -matter of metaphors, ontological metaphors.

But our conceptual system is not something we are normally aware of. In most of the little things we do every day, we simply think and act more or less automatically along certain lines. Just what these lines are, is by no means obvious. One way to find out is by studying language. Since the communication is based on the conceptual system that we use in thinking and acting, language is an important sources of evidence for what that system is like.

Mambere Tungkot, Duda Duda and Sulang - Sulang Pahompu' is one of the evidence of the use of ontological metaphors that enrich the nature of language. This is said so because in the utterances uttered while the Batak Simalungunese tradition consists of the ontological metaphorical language. It can be proven by these following evidences:

The parsahap 'master ceremony', orang tua 'parents', niombah 'children' in Batak Simalungun tradition "Mambere Tungkot, Sulang-Sulang ampa Duda-Duda Pahompu”, used human qualities are given to non- human interacting and communicating among them.

\section{CONCLUSION}

The manner of delivering metaphor, in this case the ontological metaphor by all the speakers in Mambere Tungkot, Sulang - Sulang ampa Duda-Duda Pahompu' is through the form of utterances. The usage of the right utterance will make no misunderstanding. There are two techniques in analyzing the data, which are transcribing all the utterances based on the role in the traditional ceremony and identifying the transcribed text by underlying and categorizing the proportion of the ontological metaphor language in the traditional ceremony party. The ontological metaphor of the napuran tiae 'betel leaf', unte pangir 'muddled lime', the new and beautiful clothes are related to the entities which abstract them to the lives of human beings, such 
as: a better life, blessings' joy, and good health, etc. This study found that ontological metaphors are pervasive in everyday life, not just in language but in thought and action. The writers suggest that if the conceptual system is largely metaphorical, then the way we think, what we experience, and what we do every day is very much a matter of metaphors, ontological metaphors. 'Mambere Tungkot, Duda Duda and Sulang - Sulang Pahompu' is one of the evidence of the use of ontological metaphors that enrich the nature of language. Furthermore, all the ontological metaphors in the traditional ceremony have some moral messages about how to appreciate and thank the parents, though it is in a very simple. The utterances use certain entities that are abstracted to the human qualities or the human qualities are given to non- human ones.

\section{REFERENCES}

Bogdan, R. C and Biklen, S. K. (1992). Qualitative Research for Education: An Introduction to Theory and Methods. Neidham Heights, MA: Allyn And Bacon.

Cooper, D. (1993) Truth and Metaphor, in F. R. Ankersmith and J. J. A. Mooij (Eds.), Knowledge and Language, 111. Dordrecht: Kluwer Academic.

Davis, C. (1998). Figurative language Examined: Metaphor, Symbols, and related Concepts. Retrieved On March 98 from http://www.cleanlanguage.co.uk/article s/articles/62/Figurative-Language-

Examined- Metaphors-Symbol-and Related-Concept/Past.html

Gibbs, R. (1994). The Poetics of Mind. Cambridge: Cambridge University Press.

Girsang, Martina and Sembiring,Milisi. (2018). The Implementation of Culture and Literature Through Mambere Tungkot in Simalungun Batak and Mere Ciken in Karo Batak: The Local Wisdom Maintenance.https:www.knepublishing. $\mathrm{com} / \mathrm{i}$

Goatly, A. (2005). The Language of Metaphor. London: Rouledge Taylor and Francis e Library.
Grice, H.P. (1975). Logic and Conversation, Speech Acts : Syntax and Semantics, 3, ed. P. Cole and J. L. Morgan. New York: Academic Press.

Ha Hong. (2014). Metaphor and Second Language Learning: The State of the Field, 18. New Zealand: Victoria University of Wellington.

Holme, R. (2004). Mind, Metaphor, and Language Teaching. New York: Palgrave Macmillan.

Kovecses, Z. (2010). Metaphor: A Practical Introduction. Second Edition. New York: Oxford University Press, Inc.

Lakoff, G. and Jhonson, M. (2003). Metaphors We Live By. Chicago: University of Chicago Press.

Shen, Y. (2000). Figurative Language. Cambridge: Cambridge University Press. Stern, Josef. (2000). Metaphor in Context. USA: Massachusetts Institute of Technology. Sumbayak, J. (2001). Refeleksi Habonaron Do Bona Dalam Adat Budaya Simalungun, Pematang Raya.

Uswati, J. and Rusdi N. R. (2012). Types and Function of Metaphor In Pasambahan Script of Wedding Party in KamangAgam. Padang: FBS Universitas Negeri Padang.

Wilkins, L. E. (2002). Metaphorical Language: Seeing and Hearing With Heart, 15. Kluwer: Academia Publisher - Plenum.

Wormelli, R. (2009). Metaphors \& Analogies: Power Tools For Teaching Any Subject. Portland, Maine: Stenhouse Publishers. 